\title{
Private Religious Displays in Public Fora
}

\author{
Daniel Parish $\dagger$
}

Every December from 1986 to 1988, Chabad-Lubavitch, a Hassidic Jewish organization, erected a menorah in a public park directly in front of City Hall in Burlington, Vermont. In 1988, the ACLU, responding to complaints about the menorah, which appeared to many to have been government-sponsored, sued the city to enjoin the display. The Second Circuit held that the display violated the Establishment Clause. ${ }^{1}$ Consequently, the menorah was taken down, and Burlington had to pay the ACLU $\$ 40,000$ in legal fees. ${ }^{2}$ One year later, the menorah was up again. This time, however, the display was considered constitutional because another group had sponsored a Christmas tree next to the menorah. ${ }^{3}$ In 1990, no one sponsored a tree, so the city decided not to permit the menorah. ${ }^{4}$ Chabad-Lubavitch, which had moved the menorah away from City Hall and added a generic holiday banner to the display, then sued the city. ${ }^{5}$ Chabad-Lubavitch lost the suit but did not despair; ${ }^{6}$ it altered the display slightly and sued again in 1991. And as a man stood in a park with his three children on a cold December evening, watching the lights of a 14-foot menorah while the Supreme Court considered whether to hear his case, he nodded toward a nearby American flag flapping from its pole and remarked to a reporter, "This is what it's all about. Freedom of religion."

Private religious displays in public fora present a legal and philosophical quandary. ${ }^{8}$ On the one hand, the Free Speech Clause

† A.B. 1990, Harvard University; J.D. Candidate 1994, University of Chicago.

${ }^{3}$ Kaplan v City of Burlington, 891 F2d 1024 (2d Cir 1989).

2 Lori Campbell, Court will look at menorah, Burlington Free Press B1 (Dec 11, 1990).

${ }^{3}$ Id.

Id. 1990).

- Laura Decher, Menorah dispute heads to court, Burlington Free Press B1 (Dec 7,

- Tom Harkin, Jews brave cold to celebrate Hanukkah, Burlington Free Press A1 (Dec 2, 1991). This suit also reached the Second Circuit, see Chabad-Lubavitch of Vermont $v$ City of Burlington, 936 F2d 109 (2d Cir 1991), cert denied, 112 S Ct 3026 (1992).

I Harkin, Jews brave cold to celebrate Hanukkah at Al.

- This quandary arises from the competing mandates of the First Amendment, which provides that "Congress shall make no law respecting an establishment of religion, or prohibiting the free exercise thereof; or abridging the freedom of speech . . . ." US Const, Amend I. 
generally prohibits content-based restrictions on private expression in the public forum. Similarly, the Free Exercise Clause specifically protects private religious expression. On the other hand, the Establishment Clause requires that the government not endorse one religion over another or religion over irreligion. When the government appears to sponsor religion by allowing private religious expression in a public forum, the doctrines collide. ${ }^{9}$

In two key cases in the 1980s, the Supreme Court attempted to define what kinds of religious displays in what kinds of locations do and do not violate the Establishment Clause. ${ }^{10}$ These attempts left courts, litigants, and scholars confused. As one attorney for the City of Burlington begged a judge during the 1990 rendition of the menorah dispute, "[Just t]ell us what's constitutional and we'll act accordingly."11

This Comment establishes clearer parameters for courts and municipalities confronted with private citizens who wish to adorn their local parks with crèches, menorahs, or reindeer-drawn sleds. The Comment tries to clarify the law that governs these cases and suggests a more coherent way to apply that law. Section I provides an overview of the Supreme Court's Establishment Clause and public forum jurisprudence as it relates to religious displays. Section II shows how disputes at the intersection of these doctrines have divided the lower courts. At the heart of these disputes lies the following question: Should the open nature of a public forum and the fact that a display is private preclude Establishment Clause challenges to that display, or is the fact that a display is located in a public forum merely one contextual factor to be considered in deciding whether a private display creates an unconstitutional perception of government endorsement of religion? Section III argues for the latter position.

Finally, Section IV offers a method for resolving this question in future cases. This method avoids analysis of the contextual meaning of religious symbols and instead focuses on identifying and eliminating a display's actual or perceived government support. This is done through a two-part mechanism: a presumption

- See Walz v Tax Commission, 397 US 664, 668-69 (1970) ("The Court has struggled to find a neutral course between the two Religion Clauses, both of which are cast in absolute terms, and either of which, if expanded to a logical extreme, would tend to clash with the other. ... The course of constitutional neutrality in this area cannot be an absolutely straight line . ....").

${ }^{10}$ Lynch v Donnelly, 465 US 668 (1984); County of Allegheny v ACLU, 492 US 573 (1989).

11 Decher, Menorah dispute at BI (cited in note 5). 
of government support for displays in public fora, coupled with a liberal allowance for disclaimers which counter the presumption. Hence, although courts cannot ignore the religious nature of these displays completely, this Comment suggests that concentration on the government's role in these cases is the easiest and best way to avoid Establishment Clause pitfalls.

\section{The Establishment Clause and Public Forum Doctrines}

\section{A. The Establishment Clause and Public Religious Displays}

Modern Establishment Clause jurisprudence begins with Everson $v$ Board of Education..$^{12}$ In an oft-quoted passage from this decision, the Court attempted to flesh out the meaning of the Establishment Clause:

Neither a state nor the Federal Government can set up a church. Neither can pass laws which aid one religion, aid all religions, or prefer one religion over another. . . . No person can be punished for entertaining or professing religious beliefs or disbeliefs, for church attendance or non-attendance. . . . Neither a state nor the Federal Government can, openly or secretly, participate in the affairs of any religious organizations or groups and vice versa. In the words of Jefferson, the clause against establishment of religion by law was intended to erect "a wall of separation between Church and State."13

In the years following Everson, the Court formulated a number of Establishment Clause inquiries, ${ }^{14}$ culminating in Lemon $v$

12330 US 1 (1947) (upholding a school board policy of reimbursing students for transportation to private schools, including sectarian schools). Exactly why the modern era of the Establishment Clause began in 1947 is uncertain. Professor Smith suggests that changes wrought in the American political landscape since 1787, and especially accelerated in the $1920 \mathrm{~s}, 30 \mathrm{~s}$, and $40 \mathrm{~s}$, irrevocably altered the parameters of the establishment debate in America. These changes (especially the growth of a pluralistic and secular culture) virtually eliminated the real possibility of a "state-established church." See Steven D. Smith, Separation and the "Secular": Reconstructing the Disestablishment Decision, 67 Tex L Rev 955,975 (1989). However, this same development raised concerns about how connected with religion the government could or should ever be. See id at 975-79.

${ }^{13}$ Everson, 330 US at 15-16, quoting Reynolds $v$ United States, 98 US 145, 164 (1890).

14 See, for example, Zorach v Clauson, 343 US 306 (1952) (holding constitutional a statute providing for the release of public school pupils from school attendance to attend religious classes); Engel $v$ Vitale, 370 US 421 (1962) (declaring unconstitutional the practice of beginning the school day with a prayer selected by the State Board of Regents); Abington School District $v$ Schempp, 374 US 203 (1963) (invalidating laws requiring that the school day begin with a reading of the Lord's Prayer or a selection from the Bible); Board of Education $v$ Allen, 392 US 236 (1968) (upholding statute requiring public schools to loan books 
Kurzman. ${ }^{15}$ In Lemon, the Court elaborated a three-pronged test, culled from previous cases, for determining whether a challenged state action violates the Establishment Clause: First, does the statute or policy in question lack a "secular legislative purpose"?" Second, is the "principal or primary effect" of the statute or policy "one that [ ]either advances [ ]or inhibits religion?"17 Third, does the statute or policy "foster 'an excessive government entanglement with religion?" "18 If the answer to any of these questions is affirmative, the statute or policy is unconstitutional.

The Court did not suppose the Lemon test to be the final word in Establishment Clause jurisprudence. ${ }^{19}$ Nonetheless, with only three exceptions, ${ }^{20}$ the Court has consistently invoked some version of the Lemon test in its Establishment Clause cases. ${ }^{21}$

The Court first applied the Lemon test to public religious displays in Lynch $v$ Donnelly. ${ }^{22}$ There a 5-4 majority held constitutional a Christmas display maintained by the city of Pawtucket,

free of charge to private schools, including parochial schools); Walz, 397 US 664 (upholding property tax exemptions for religious organizations).

16403 US 602 (1971).

${ }^{16}$ Id at 612.

17 Id.

${ }^{18}$ Id at 613 , quoting Walz, 397 US at 674.

18 As Chief Justice Burger admitted, "[c]andor compels acknowledgment . . . that we can only dimly perceive the lines of demarcation in this extraordinarily sensitive area of constitutional law." Lemon, 403 US at 612.

${ }^{20}$ The three exceptions are Marsh v Chambers, 463 US 783 (1983), Larson v Valente, 456 US 228 (1982), and Lee $v$ Weisman, 112 S Ct 2649 (1992). In Marsh, the Court upheld the Nebraska state legislature's practice of having a paid chaplain open sessions with a prayer. The Court did so on the basis of a tradition, common to many American legislatures, that predates the First Amendment. 463 US at 787, 794-95. Justice Brennan argued in dissent that the practice would have failed any reasonable application of the Lemon test. Id at 797-801 (Brennan dissenting).

In Larson, the Court invalidated a statute that imposed registration requirements on religious organizations soliciting more than $50 \%$ of their funds from nonmembers. 456 US at 249-51. Although the Court did not rely on Lemon, the Court still noted that a Lemon analysis would have produced the same result. Id at 252-53.

In Lee, the Court reached its decision on the basis of coercive behavior without relying on Lemon. See text accompanying notes 58-69.

${ }^{21}$ In addition to the cases discussed in the text below, this list includes, among others, Bowen v Kendrick, 487 US 589, 602 (1988); Edwards v Aguillard, 482 US 578, 583 (1987); Witters $v$ Washington Department of Services for the Blind, 474 US 481, 485 (1986); Grand Rapids School District v Ball, 473 US 373, 382-83 (1985); Estate of Thornton v Caldor, Inc., 472 US 703, 708 (1985); Wallace v Jaffree, 472 US 38, 55-56 (1985); Larkin v Grendel's Den, Inc., 459 US 116, 123 (1982); Stone v Graham, 449 US 39, 40 (1980); Committee for Public Education v Regan, 444 US 646, 653 (1980); Sloan v Lemon, 413 US 825, 829-33 (1973); Committee for Public Education v Nyquist, 413 US 756, $772-73$ (1973).

${ }^{22} 465$ US 668 (1984). 
Rhode Island in a private park. ${ }^{23}$ Retreating from the language of Everson and Lemon, the Court noted that Thomas Jefferson's wall of separation "is a useful figure of speech" but "is not a wholly accurate description of the practical aspects of the relationship that in fact exists between church and state." ${ }^{24}$ The Court also recognized the importance of the American religious heritage and the limitations of the Lemon test in defining the line between proper respect for this tradition and impermissible government involvement in religion. ${ }^{25}$ But the Court nonetheless employed the Lemon test, holding that the government did not have an exclusively religious purpose in erecting the display and that the display, in its context, ${ }^{26}$ did not have the primary effect of endorsing religion. ${ }^{27}$

Concurring in the judgment, Justice O'Connor invoked a "clarified" Lemon test that divided the Establishment Clause inquiry into two parts: 1 ) whether the government activity causes "excessive entanglement with religious institutions," and 2) whether the government's behavior constitutes "endorsement or disapproval of religion." 28 The "endorsement" test, as it has become known, combines the purpose and effects prongs of the Lemon test. It asks explicitly what the Lemon test implies: Does the government "subjectively" intend to endorse religion, or could an audience "objectively" interpret the government's actions as endorsing religion? ${ }^{29}$ The endorsement test prohibits both.

Employing this new synthesis, Justice O'Connor found that the government had a legitimate secular purpose: the celebration of a public holiday. ${ }^{30}$ Similarly, the "overall holiday setting" of the crèche amidst "purely secular symbols" could not reasonably be

${ }^{23}$ Id at 671-72. The display contained a crèche and, among other things, a Santa Claus house, reindeer pulling Santa's sleigh, candy-striped poles, a Christmas tree, carolers, a clown, an elephant, a teddy bear, and a banner that read "SEASONS GREETINGS." Id.

24 Id at 673, citing reply from Thomas Jefferson to an address by a committee of the Danbury Baptist Association (Jan 1, 1802) as quoted in Reynolds v Sims, 98 US 145, 164 (1879).

25465 US at $674-79$.

28 Dispute has arisen as to what Lynch meant by "context." Some read it as referring only to the holiday season in general. Others see it as indicating that the particular items surrounding a religious display may "secularize" the display; in Lynch, this meant the clown, the elephant, etc. See Note, Constitutional Law: Religious Displays on Government Property: Where Do We Stand?, 43 Okla L Rev 375, 382 (1990). See also Section IV.A.

${ }^{27}$ Lynch, 465 US at 681 . The dissent found that both of these prongs of Lemon had been violated. Id at 698-702 (Brennan dissenting).

${ }^{28}$ Id at $687-88$ ( $O^{\prime}$ Connor concurring).

20. Id at 690 .

${ }^{30}$ Id at 691-92. 
understood to "communicate a message that the government intends to endorse the Christian beliefs represented by the crèche."

Five years and a number of lower court decisions later, ${ }^{32}$ the Court decided County of Allegheny $v$ ACLU. ${ }^{33}$ The Allegheny Court, in shifting majorities, held a privately erected crèche displayed in a county courthouse stairway unconstitutional but held a privately sponsored menorah located on public ground near another city building constitutional. ${ }^{34}$ In reaching this decision, Justice Blackmun's plurality opinion appealed to a developing endorsement test that interprets "[ $t]$ he Establishment Clause [as], at the very least, prohibit[ing] government from appearing to take a position on questions of religious belief or from 'making adherence to a religion relevant in any way to a person's standing in the political community." "35 Justice Blackmun criticized the Lynch majority opinion as "none too clear" and praised the "sound analytical framework" developed by Justice O'Connor, noting two advantages of the endorsement test. ${ }^{36}$ First, the test "squarely rejects any notion that this Court will tolerate some government endorsement of religion." 37 Second, the test emphasizes the importance of context for determining whether a display or practice is unconstitutional. ${ }^{38}$

With five Justices adopting the endorsement test, the Court held 5-4 that the crèche, a clearly religious symbol, unconstitution-

${ }^{32}$ Id at 692. Justice O'Connor also dismissed claims that the "political divisiveness" potentially engendered by the crèche caused excessive entanglement with religion because there was no "institutional entanglement." Id at 689.

${ }^{32}$ Contrast American Jewish Congress v Chicago, 827 F2d 120, 121-22 (7th Cir 1987) (distinguishing Lynch and finding a crèche situated by itself in the lobby of a city building an unconstitutional display); ACLU v City of Birmingham, 791 F2d 1561, 1566-67 (6th Cir 1986) (applying Justice O'Connor's endorsement test and finding that a crèche standing alone was unconstitutional); Smith $v$ County of Albemarle, 895 F2d 953, 958 (4th Cir 1990). (holding that a nativity scene erected by a private group on the front lawn of a county office building violated the Establishment Clause); and Burelle $v$ City of Nashua, 599 F Supp 792, 797 (D NH 1984) (holding that a crèche on the grounds of a government building, unaccompanied by secular symbols, violated the Establishment Clause); with McCreary v Stone, 739 F2d 716, 725-30 (2d Cir 1984), aff'd by an equally divided Court as Scarsdale $v$ McCreary, 471 US 83 (1985) (holding that a lone nativity scene displayed with a disclaimer in a public park was constitutional under $L y n c h)$.

33492 US 573 (1989).

${ }^{34}$ Id at 578-79.

${ }^{36}$ Id at 594, quoting Lynch, 465 US at 687 (O'Connor concurring). Justice Blackmun cited Wallace v Jaffree, 472 US 38, 60 (1985), Grand Rapids School District $v$ Ball, 473 US 373, 389-92 (1985), and Texas Monthly, Inc. v Bullock, 489 US 1, 17 (1989) (plurality opinion), as signposts along the way to the Allegheny decision. 492 US at 592-93.

${ }^{36} 492$ US at $594-95$.

${ }^{37}$ Id at 595. Note that Chief Justice Burger's opinion in Lynch essentially tolerated just such endorsement. See text accompanying notes 24-27.

${ }^{38} 492$ US at 595. 
ally stood in the heart of a government center, a setting that did "not appear to be the kind of location in which all were free to place their displays for weeks at a time . . .."39 As Justice Blackmun stated, "[n]o viewer could reasonably think that [the crèche] occupies this location without the support and approval of the government." 40 Neither a sign indicating that a Catholic organization owned the crèche, nor regular performances by Christmas carolers near the crèche, nor the occasional use of the stairway for other displays at other times was enough to dispel this endorsement. ${ }^{41}$

In contrast, the Court held 6-3 that the menorah display was constitutional. Justice Blackmun found the menorah acceptable because it stood next to a large Christmas tree, a secular symbol. ${ }^{42}$ This did not mean that "simultaneous endorsement of Judaism and Christianity" is constitutionally acceptable, ${ }^{43}$ but rather that the display merely recognized a secular winter-holiday season of which Chanukah had become a part.44

Justice Kennedy, joined by three other Justices, concurred in part, dissented in part, and condemned the "endorsement" test as an unworkable standard that "reflects an unjustified hostility toward religion, a hostility inconsistent with our history and our precedents . . . ."45 According to Justice Kennedy, the Establishment Clause only mandates neutrality with regard to religion. This neutrality "permits government some latitude in recognizing and accommodating the central role religion plays in our society." ${ }^{46} \mathrm{Ap}$ pealing to the American religious heritage, Justice Kennedy proposed a new test:

38 Id at $600 \mathrm{n} 50$.

to Id at 599-600. The county had also, at its own expense, placed poinsettias and two small evergreens around the crèche. Id at 580 . By creating a "visual link" between itself and the display the government could not deny it had endorsed the display. Id at $600 \mathrm{n} 50$.

11 Id at 599-600.

42 Id at 616-18.

43 Id at 615 .

44 Id at 616. Justice Blackmun called the Christmas tree a secular symbol and the menorah a religious one. But somehow, the tree, because it dwarfed the menorah, let the menorah be "understood as simply a recognition that Christmas is not the only traditional way of observing the winter-holiday season." Id at 617 . Additionally, the unavailability of an alternative, reasonable symbol of Chanukah (Justice Blackmun rejected a novel solution: a large dreidel), allowed the menorah to take on a secular purpose. Id at 618. Justice O'Connor agreed that the Chanukah display represented no endorsement of religion but disavowed Justice Blackmun's somewhat awkward search for a secular alternative to a menorah. Id at 636-37 (O'Connor concurring).

is Id at 655 (Kennedy concurring in part and dissenting in part). Chief Justice Rehnquist and Justices White and Scalia joined Kennedy's opinion.

18 Id at 656-57. 
Our cases disclose two limiting principles: government may not coerce anyone to support or participate in any religion or its exercise; and it may not, in the guise of avoiding hostility or callous indifference, give direct benefits to religion in such a degree that it in fact "establishes a [state] religion or religious faith, or tends to do so." 47

Under this "coercion" test, ${ }^{48}$ Justice Kennedy would have found no Establishment Clause violation in permitting private actors to display a crèche; the county was merely accommodating the free exercise of religion. ${ }^{49}$

Justice Kennedy dismissed Justice Blackmun's contextual arguments on three grounds. First, Justice Blackmun had misread Lynch. To Justice Kennedy, Lynch did not stand for the proposition that secular items near a religious display dissipated the display's religious effect. ${ }^{\circ 0}$ The Lynch "context" argument referred only to the context of the Christmas season in general. Second, the endorsement test and its invocation of a "reasonable observer" were supported by neither precedent nor reason. ${ }^{51}$ The endorsement test necessitated a ridiculous "jurisprudence of minutiae" that asked such questions as "whether the city has included santas, talking wishing wells, reindeer or other secular symbols."

47 Id at 659 , quoting Lynch, 465 US at 678. 602.

48 Justice Blackmun referred to this as a "proselytization" test. Allegheny, 492 US at

49 Id at 664 .

so Justice Kennedy noted:

Nothing in Chief Justice Burger's opinion for the Court in Lynch provides support for these purported distinctions. . . . Crucial to the Court's conclusion was not the number, prominence, or type of secular items contained in the holiday display but the simple fact that, when displayed by government during the Christmas season, a crèche presents no realistic danger of moving government down the forbidden road toward an establishment of religion.

Id at 665-66.

52 Id at $668-69$.

82 Id at 674-75. Critics have labeled this the "Saint Nicholas too" test. Judge Nelson appears to have coined the phrase. See ACLU v City of Birmingham, 791 F2d 1561, 1569 (6th Cir 1986) (Nelson dissenting). The other common epithet, the "two plastic reindeer rule," has more uncertain origins, although the first recorded use, as revealed by a NEXIS search, was on a MacNeil/Lehrer News Hour broadcast on December 13,1984. By the time the phrase appeared in a newspaper eight days later, the decision was already "now often known as the "two plastic reindeer rule." Nancy Dunne, Putting Christ back into Christmas, Financial Times I4 (Dec 21, 1984). For more such rhetoric, see American Jewish Congress v Chicago, 827 F2d 120, 130 (7th Cir 1987) (Easterbrook dissenting) ("It would be appalling to conduct litigation under the Establishment Clause as if it were a trademark case, with experts testifying about whether one display is really like another, and witnesses testifying they were offended-but would have been less so were the crèche five feet closer to the jumbo candy cane."). 
the endorsement test ignored the relevance of history and "historical patterns" in justifying certain practices. ${ }^{.3}$

Justice O'Connor, in turn, defended her endorsement test against Justice Kennedy's attack, especially its supposedly ahistorical character. She noted that the test necessarily takes into account long-standing practices because such practices "provide[] part of the context in which a reasonable observer evaluates whether a challenged governmental practice conveys a message of endorsement of religion." 54

Justices Brennan and Stevens, each concurring in part and dissenting in part, agreed with the Court's analysis of the crèche but felt that Justices Blackmun and O'Connor lacked the courage of their convictions when it came to the menorah. ${ }^{55}$ They argued that if a Christmas tree is secular and a menorah religious, then "the scene is about Judaism, not about pluralism."

Allegheny marked the first time a majority of the Court explicitly relied on the endorsement test. However, given the logistical confusion of Allegheny's multiple opinions, the endorsement test's ascendancy was not complete. Three contenders for an Establishment Clause test therefore remained: the Lemon test, the endorsement test, and the coercion test. ${ }^{57}$ Lee $v$ Weisman, the Court's next important pronouncement on the Establishment Clause, added another. ${ }^{58}$

In Lee, the Court declared unconstitutional a policy of the Rhode Island public school system that permitted school principals to invite local clergymen to deliver invocation and benediction

ss Allegheny, 492 US at 669-70 (Kennedy concurring in part and dissenting in part).

s4 Id at 630 (O'Connor concurring).

ss Id at 639-41 (Brennan concurring in part and dissenting in part) ("In my view, this attempt to take the 'Christmas' out of the Christmas tree is unconvincing."); id at 654-55 (Stevens concurring in part and dissenting in part).

${ }^{B B}$ See id at 640 (Brennan); id at 645 (Stevens).

s7 As one commentator understated, "the future direction of establishment clause jurisprudence is unclear." Donald Beschle, Paradigms Lost: The Second Circuit Faces the New Era of Religion Clause Jurisprudence, 57 Brooklyn L Rev 547 (1991). Professor Levy is less generous: "[T]he Court has managed to unite those who stand at polar opposites on the results that the Court reaches; a strict separationist and a zealous accomodationist are likely to agree that the Supreme Court would not recognize an establishment of religion if it took life and bit the Justices." Leonard Levy, The Establishment Clause: Religion and the First Amendment 163 (MacMillan, 1986). Compare Michael W. McConnell, Religious Participation in Public Programs: Religious Freedom at a Crossroads, 59 U Chi L Rev 115 (1992) ("I stand at a pole opposite to Levy on most of these issues, but I agree with that assessment.").

ss 112 S Ct 2649 (1992). Although Lee does not address the issue of religious displays directly, it is evidence of the continuing drift of Establishment Clause jurisprudence. See also Lamb's Chapel v Center Moriches Union Free School District, 113 S Ct 2141 (1993), discussed in text accompanying notes 100-102. 
prayers at graduation ceremonies. Justice Kennedy, writing for the five-member majority, noted the essentially obligatory nature of such ceremonies and declared the practice to be an attempt to "compel a student to participate in a religious exercise." Kennedy couched his opinion in the language of coercion: "It is beyond dispute that, at a minimum, the Constitution guarantees that government may not coerce anyone to support or participate in religion or its exercise, or otherwise act in a way which 'establishes a [state] religion or religious faith, or tends to do so." "60 However, this opinion did not mark the victory of the coercion test. Given that no one ever doubted that the endorsement and Lemon tests already included the concept of coercion, the opinion represents only a temporary alliance between the tests. ${ }^{61}$

In fact, Lee revealed a split in the coercion test analysis, a split between direct and indirect coercion. ${ }^{62}$ Justice Kennedy opted for indirect coercion, a test that acknowledges that the Establishment Clause prohibits more than the government's actually forcing a person to practice a particular religion. ${ }^{63}$ In Justice Kennedy's view, the "reasonable perception" of being "forced" to participate in a religious activity constitutes an Establishment Clause viola-

s9 Lee, $112 \mathrm{~S} \mathrm{Ct}$ at 2661 .

${ }^{60}$ Id at 2655 (citations omitted).

B1 See Justice Blackmun's concurrence: "I join the Court's opinion today because I find nothing in it inconsistent with the essential precepts of the Establishment Clause developed in our precedents." Id at 2664 (Blackmun concurring). See also Committee for Public Education $v$ Nyquist, 413 US 756, 786 (1973) (noting that coercion is "not a necessary element of any claim under the Establishment Clause").

The Court's most recent Establishment Clause opinion, Lamb's Chapel, $113 \mathrm{~S}$ Ct 2141, demonstrated just how fragile the alliance in Lee was. Although the Lamb's Chapel Court held unanimously that a public school could not deny a church's request to use school facilities during non-school hours when the school opened its facilities to others, id at 2147, Justice Kennedy wrote a separate concurring opinion to emphasize that he did not base his decision on any sort of "endorsement" test. Id at 2149 (Kennedy concurring).

Judge Easterbrook has also made the point that such marriages of convenience are bound to occur in areas such as Establishment Clause jurisprudence, where more than two legal positions are possible on a given issue. The result is an unstable doctrine. See Frank Easterbrook, Ways of Criticizing the Court, 95 Harv L Rev 802, 815-17 (1982).

${ }_{62}$ Various remarks in the several Allegheny opinions had hinted at the potential for such a schism. See, for example, 492 US at 628 (O'Connor concurring) ("Moreover, even as Justice Kennedy recognizes, any Establishment Clause test limited to 'direct coercion' clearly would fail to account for forms of "[s]ymbolic recognition or accommodation of religious faith' that may violate the Establishment Clause.").

${ }^{63}$ Lee, $112 \mathrm{~S} \mathrm{Ct}$ at 2658 (noting that the pressure to participate in a religious invocation at a graduation ceremony, "though subtle and indirect, can be as real as any overt compulsion"). 
tion. ${ }^{64}$ On the other hand, Justice Scalia argued in dissent for a more stringent definition of coercion: "I see no warrant for expanding the concept of coercion beyond acts backed by threat of penalty . . . ." with him, the consequences of having to listen to public prayers were innocuous and insufficient to warrant constitutional protection. $^{68}$

Hence, Lee actually expanded the Establishment Clause debate by revealing two variations on the coercion test. ${ }^{87}$ And as concurrences by Justices Blackmun and Souter revealed, the endorsement test remains alive and well. ${ }^{68}$ Moreover, although it did not apply the Lemon test, the Court in Lee expressly refused invitations to reconsider Lemon. ${ }^{69}$ Thus, the Court has provided at least four tests: Lemon, endorsement, indirect coercion, and direct coercion, any of which might be used to analyze the constitutionality of private religious displays on public property..$^{70}$ Were that not enough, the issue also implicates an entirely separate body of jurisprudence: the public forum doctrine.

\section{B. Public Forum Doctrine and Religious Displays}

At first glance, "[i]t is strange that a government can violate the Establishment Clause by tolerating free speech. . . . [But a]t some point . . . a private religious group may so dominate a public forum that a formal policy of equal access degenerates into endorsement."71 For that reason, an analysis of the constitutional limits on private religious displays requires consideration of the

64 Id. Justice Kennedy tailored his remarks to the special psychological circumstances of children participating in a graduation ceremony. Id at 2658-59.

Bs Id at 2684 (Scalia dissenting). The tone of Justice Scalia's dissent parallels that of Justice Kennedy's dissent in Allegheny. See text accompanying notes 45-53.

${ }^{68} 112 \mathrm{~S} \mathrm{Ct}$ at 2681-82.

${ }^{67}$ Professor Sherry argues that the Court adopted a coercion test in Lee, although the dissent found none on the facts of the case. See Suzanna Sherry, Lee v Weisman: Paradox Redux, 1992 S Ct Rev 123, 131-33.

o8 Justice Souter criticized Justice Scalia's "direct" coercion standard by noting that "a literal application of the coercion test would render the Establishment Clause a virtual nullity" since the free exercise clause in and of itself already militates against any direct coercion. Id at 2673 (Souter concurring). See also Allegheny, 492 US at 628 (O'Connor concurring); Abington School District v Schempp, 374 US 203, 233-34 (1963); Douglas Laycock, "Nonpreferential" Aid to Religion: A False Claim About Original Intent, 27 Wm \& Mary L Rev 875, 922 (1986).

${ }^{89}$ Lee, $112 \mathrm{~S} \mathrm{Ct}$ at 2655.

70 Admittedly, these tests do not have equal claims to legitimacy.

${ }^{71}$ Doe v Small, 964 F2d 611, 624-25 (7th Cir 1992) (Cudahy concurring). 
Court's public forum doctrine. ${ }^{72}$ The Supreme Court has divided public fora into three categories: traditional public fora, designated or limited public fora, and closed public property. ${ }^{73}$ As might be expected, the more open the forum, the greater the right to free speech or free expression therein. ${ }^{74}$

Speech in streets, parks and other traditional open public fora is accorded the widest latitude. ${ }^{75}$ The Court disfavors contentbased restrictions on speech in such open fora, requiring "a compelling state interest" justifying the restrictions as well as proof that these restrictions "are narrowly drawn to achieve that end.""76

Limited or designated public fora are areas to which the public does not traditionally have access but "which the state has opened for use by the public as a place for expressive activity."77 So long as the state maintains such a forum, the government must allow free speech there as if it were a traditional public forum. ${ }^{78}$ This category may include state universities, ${ }^{78}$ public high schools, ${ }^{80}$ municipal theaters, ${ }^{81}$ and other similar facilities. Additionally, limited public fora may be created for use by a particular group only; a public university, for example, might be an open forum for its students but not for the public at large ${ }^{82}$ Where the opening has been limited to one group, that group has the same broad free speech rights in that forum as it would have on a public street, although others would not have these rights. ${ }^{83}$

${ }^{22}$ It is settled doctrine that religious expression is protected by the First Amendment's free speech guarantee as well as by the Free Exercise clause. See Heffron $v$ International Society for Krishna Consciousness, Inc., 452 US 640, 647 (1981).

${ }^{73}$ Perry Education Ass'n v Perry Local Educators' Ass'n, 460 US 37, 45-46 (1983).

74 Id at 44.

${ }^{76}$ See Hague $v$ CIO, 307 US 496 (1939).

${ }^{76}$ Perry, 460 US at 45 . The Court recently reaffirmed this stance in International Society for Krishna Consciousness, Inc. v Lee, 112 S Ct 2701, 2705 (1992) ("ISKCON"). See also Boos v Barry, 485 US 312, 321-22 (1988).

77 Perry, 460 US at 45.

${ }^{78}$ Id at $45-46$; ISKCON, $112 \mathrm{~S} \mathrm{Ct}$ at 2705.

79 Widmar v Vincent, 454 US 263, 267-68 (1981). See also Comment, University Regulation of Student Speech: Considering Content-Based Criteria Under Public Forum and Subsidy Doctrines, 1991 U Chi Legal F 393, 396-7 (arguing that universities should be categorized as public or semi-public fora and accorded greater discretion in regulating speech).

so Board of Education v Mergens, 496 US 226, 235-36, 252 (1990).

s1 Southeastern Promotions, Ltd. v Conrad, 420 US 546, 555 (1975).

s2 See Widmar, 454 US at 267 n 5.

ss Id. 
The third category, closed public property, includes areas owned by the government but not typically open to the public. ${ }^{84}$ Regulation of speech there need only be "reasonable."

The Court first considered restrictions on religious speech in a public forum in Widmar $v$ Vincent. ${ }^{88}$ There a public university refused to allow student religious groups to conduct meetings in university facilities. The Court held that the university constituted a limited public forum, ${ }^{87}$ so that the First Amendment protected the students' right to free religious expression in that forum..$^{8 \mathbf{8}}$

The Court then noted that in situations " "[w] has opened a forum for direct citizen involvement,' exclusions bear a heavy burden of justification."89 Avoiding a violation of the Establishment Clause, the Court decided, would meet that burden as a "compelling state interest" that would justify regulating or prohibiting some speech or exercise of religion. ${ }^{80}$

To see if allowing religious groups to use university facilities would violate the Establishment Clause, the Court trotted out the Lemon test. Applying Lemon, the Court quickly dismissed the idea that an open forum policy lacked a valid secular purpose or caused unnecessary entanglement with religion. ${ }^{91}$ With regard to the

84 This category includes a great deal of public property, from the Oval Office to the janitor's closet at city hall.

${ }^{85}$ Perry, 460 US at 46; ISKCON, $112 \mathrm{~S}$ Ct at 2705-06 ("The challenged regulation need only be reasonable, as long as the regulation is not an effort to suppress the speaker's activity due to disagreement with the speaker's view."). The Allegheny crèche, for example, sat in a closed public forum. Allegheny, 492 US at $600 \mathrm{n} 50$.

${ }^{86} 454$ US 263 (1981). Although Widmar marked the first time the Court applied its public forum doctrine to religious expression, the Court had dealt with restrictions on public religious speech in earlier cases. See, for example, Saia v New York, 334 US 558 (1948) (Jehovah's Witnesses may use loudspeakers in public parks without prior permission); Cantwell $v$ Connecticut, 310 US 296 (1940) (person may broadcast religious messages on a public street even where those messages offend others).

87 454 US at 267-68.

ss Id at 269. In dissent, Justice White argued that the government could ban religious speech as a class from the public forum, maintaining that the Religion Clauses permitted such a restriction. Moreover, he contended, the majority's extension of public forum guarantees to religious expression would make the Free Exercise Clause redundant. Id at 282-84. The argument was and is unpersuasive. See Douglas Laycock, Equal Access and Moments of Silence: The Equal Status of Religious Speech by Private Speakers, $81 \mathrm{Nw}$ U L Rev 1, 11 (1986) (arguing that just because the government cannot express religious opinions itself does not mean that it can censor religious speech by private individuals).

Bo Widmar, 454 US at 268, quoting Madison Joint School District $v$ Wisconsin Employment Relations Comm'n, 429 US 167, 175 \& n 8 (1976).

${ }^{\circ 0} 454$ US at 271. See also Comment, $1991 \mathrm{U}$ Chi Legal F at 412 (cited in note 79) ("Despite its status as a public forum, a university may consider some content-based criteria in regulating student speech.").

9145 US at 271-72. 
Lemon effects prong, the Court found that "[i]t is possible-perhaps even foreseeable-that religious groups would benefit from access to [u]niversity facilities." ${ }^{22}$ However, the benefit religion received from the policy would be "incidental" and would "not violate the prohibition against the 'primary advancement' of religion." "The Court therefore held that the university had not supplied a sufficient justification for excluding the religious groups from its facilities. ${ }^{94}$

Nearly a decade later, the Court held in Board of Education $v$ Mergens that Widmar's logic could extend to public secondary schools. $^{95}$ Mergens held that the Equal Access Act, ${ }^{96}$ which required a school to permit students to form religious clubs if the school also permitted other, non-curriculum-related clubs, did not violate the Establishment Clause. ${ }^{97}$ The Court noted that "there is a crucial difference between government speech endorsing religion, which the Establishment Clause forbids, and private speech endorsing religion, which the Free Speech and Free Exercise Clauses protect."98 Furthermore, "secondary school students are mature enough and are likely to understand that a school does not endorse or support student speech that it merely permits on a nondiscriminatory basis."

Finally, in Lamb's Chapel v Center Moriches Union Free School District, the Court unanimously held that a public school could not deny a religious group's request to use school facilities during non-school hours if the school opened its facilities to others. ${ }^{100}$ Relying on Widmar and Lemon, the Court suggested that the Establishment Clause, by prohibiting the school district from appearing to endorse the group's religion, could provide a

92 Id at 273.

${ }^{83}$ Id, quoting Committee for Public Education v Nyquist, 413 US 756, 771 (1973).

94 454 US at $276-77$.

9s 496 US 226, 248-49 (1990). Bridget Mergens, the plaintiff, wanted to start a Christian club at her high school, and the school had refused her request. According to school policy, all clubs required a faculty sponsor, and the administration feared that allowing a faculty member to sponsor a Christian club would violate the Establishment Clause. Id at 231-33.

${ }^{96}$ Pub L No 98-377, 98 Stat 1302 (1984), codified at 20 USC \$§ 4071-74 (Supp V 1987).

${ }^{97}$ Mergens, 496 US at 247-48. In fact, the Court restricted its holding to deciding that the school's refusal to let a student form a Christian club violated the Act. The Court determined that "we need not decide-and therefore express no opinion on-whether the First Amendment requires the same result." Id at 247.

83 Id at 250.

99 Id. The Court also emphasized Congress's specific rejection of the notion that students would likely "confuse an equal access policy with state sponsorship of religion." Id at 250-51.

100113 S Ct 2141 (1993). 
compelling reason not to permit this use of school facilities. ${ }^{101}$ However, the facts of Lamb's Chapel did not present this reason: "Under these circumstances, as in Widmar, there would have been no realistic danger that the community would think that the District was endorsing religion or any particular creed, and any benefit to religion would have been no more than incidental." 102

Widmar, Mergens, and Lamb's Chapel clearly establish that private religious speakers do have free speech rights in limited and open public fora. But as the applications of Lemon in Widmar and Lamb's Chapel demonstrate, the Establishment Clause still retains some power in public fora, as the Clause permits state officials to exclude religious speakers when the religious speech would violate the Lemon test. How to reconcile these doctrines has divided lower courts.

\section{Disputes Over Private Religious Displays in Public Fora}

Far from resolving the analytical problems created by Lemon and Lynch and the fact-sensitive nature of Establishment Clause inquiries, Allegheny and Lee only provided more ammunition for what is naturally a heated battle. Not surprisingly, lower courts have divided over how much deference to grant private religious expression in public fora. At one end of the spectrum, courts have concluded that the concerns of free speech and expression outweigh those of the Establishment Clause. Under this view, application of the Establishment Clause to these cases is superfluous and misguided. At the other end, some courts have held that the public forum doctrine must give way to the Establishment Clause. For these courts, the public forum is merely another contextual factor to be considered in determining whether a religious display implicates the Establishment Clause.

The Sixth, Seventh, Ninth and Eleventh Circuits have taken the lead in emphasizing the public forum doctrine over the Establishment Clause. In Americans United for Separation of Church and State v City of Grand Rapids ("Americans II"), the Sixth Circuit held constitutional a privately funded menorah placed in a central public plaza. ${ }^{103}$ The court emphasized the free speech

101 Id at 2148.

102 Id.

103980 F2d 1538, 1554 (6th Cir 1992) (en banc). A Hassidic Jewish organization owned and paid for the maintenance of the display. Id at 1539-40. The Sixth Circuit had vacated the panel decision, 1992 US App LEXIS 7513 ("Americans I"), and granted rehearing, 60 USLW 2694 (1992). Americans II reversed the lower court's decision by a 9-6 vote. 
rights enjoyed by private citizens and held that the rights extended to the display of a menorah. ${ }^{104}$ Having thus decided, the court embarked on a hybrid Lemon-endorsement test analysis. Noting that the Establishment Clause concerns government and not private behavior, the court focused on the city's creation and maintenance of a public forum. ${ }^{105}$ Consequently, the court dismissed the notions that the government's purpose in establishing a public forum was to promote religion or that the creation of such a forum entangles government and religion. ${ }^{108}$ Turning to the effects prong of Lemon, the court determined that a reasonable observer ${ }^{107}$ would not have viewed the display as a government endorsement of religion. ${ }^{108}$

Similarly, the Americans II court reasoned that if Widmar, Mergens, and other cases held in favor of free religious expression in limited public fora, then the city could not exclude the menorah from its central plaza, an open public forum. ${ }^{109}$ The court concluded, "[W]e rule in favor of Grand Rapids and Chabad House, because we hold that truly private religious expression in a truly public forum cannot be seen as endorsement by a reasonable observer."110 Three other circuit courts of appeals have reached similar conclusions. ${ }^{111}$

104980 F2d at 1542.

108 Id at 1541-42.

${ }^{108}$ Id at 1543.

${ }^{107}$ Much of the debate in Americans $I I$ focused on a definition of the "reasonable observer." The Americans $I I$ court defined her as a "reasonable person knowing all the relevant facts." Id at 1543-44. See discussion in Section III.B. See also Kreisner v City of San Diego, 1 F3d 775, 784 (9th Cir 1993) (following Americans IT's reasoning on this point).

${ }_{108}$ Americans $I I, 980$ F2d at 1548-49. The Americans II court distinguished Allegheny on the grounds that 1) the Allegheny crèche sat in a privileged location, 2) Allegheny County associated itself with the crèche through press releases, and 3) the county had created a visual link between its own symbols in the courthouse and those in the crèche display. Id at 1545, citing Allegheny, 492 US at $600 \mathrm{n} 50$.

${ }^{108} 980 \mathrm{~F} 2 \mathrm{~d}$ at 1549.

${ }^{110}$ Id at 1553. See also Congregation Lubavitch v City of Cincinnati, 997 F2d 1160, 1164 (6th Cir 1993) (following Americans $I I$ ).

${ }^{111}$ In Doe v Small, 964 F2d 611, 622 (7th Cir 1992) (en banc), the Seventh Circuit unanimously declared an injunction against a Christmas display of religious paintings in a city park by the Jaycees, a private group, overbroad and an infringement of First Amendment free exercise rights. The city had passed a resolution endorsing the Jaycees' activities, and the mayor had made official comments approving of the paintings. The court nonetheless decided after its review of Widmar that "the Supreme Court has refused to find the Establishment Clause to be a sufficiently compelling interest to exclude private religious speech even from a limited public forum created by the government." Id at 618 . By analogy, therefore, a court cannot exclude private actors from an open public forum "merely because of the religious content of their speech." Id at 619 (emphasis omitted).

The unanimity of the Doe judgment actually belies a sharp split in the Seventh Circuit. Concurrences by Cudahy and Flaum, which attracted the support of five of the eleven judges, take positions far closer to those of the Second and Fourth Circuits. Id at 622 
In contrast, the Second and Fourth Circuits have found unaccompanied private religious displays in public fora to be unconstitutional. In Kaplan $v$ City of Burlington, ${ }^{112}$ a case with facts similar to those in Americans II, the Second Circuit held that the public display of a private menorah near city hall violated the Establishment Clause. ${ }^{113}$ Rejecting the notion that the public forum doctrine conveyed "an absolute constitutional right to engage in symbolic expressive conduct," the court remarked that an unlimited right to express any religious view in the public forum "would swallow up the Establishment Clause."114 And, the court noted, content-based exclusions are sometimes "necessary to serve a compelling state interest," such as upholding the Establishment Clause. ${ }^{115}$

(Cudahy concurring); id at 628 (Flaum concurring) (noting that even though the display had private sponsors, "what must be considered is whether all of the City's actions, in their entirety, sufficiently impact present perceptions of the display so as to warrant remedial relief").

It should also be noted that the procedural posture of Doe was somewhat bizarre. A lower court had held that the city violated the Establishment Clause by endorsing the art work, and the city did not appeal this decision. Instead, the Jaycees intervened and appealed. Id at 617 . Hence, the issue on appeal was not whether the city had violated the Establishment Clause; it had. Rather, the question was whether the paintings (the religious speech itself) had somehow been tainted by this endorsement, and whether a complete ban on the display in the park was overbroad. See id at 623-24 (Cudahy concurring). The court's unanimity extended only to the finding that this particular remedy, a complete ban, was too extreme. Id at 622 .

The Ninth Circuit reached a similar conclusion in Kreisner $v$ City of San Diego, 1 F3d 775 (9th Cir 1993). There, San Diego permitted a private organization to erect life-size statues depicting the life of Christ in a municipal amphitheater. Using a Lemon test analysis, the court determined that the display, because it was "private speech in a traditional public forum removed from the seat of government," did not have the effect of advancing religion. Id at 782. Nor did the city's regulations lack a secular purpose, id, or entangle the city in religion. Id at 789 .

The Eleventh Circuit recently adopted this viewpoint as well. See Chabad-Lubavitch of Georgia v Miller, 5 F3d 1383 (11th Cir 1993) (en banc), reversing 976 F2d 1386 (11th Cir 1992). The ever-busy members of Chabad sought to place a menorah in the rotunda of the State Capitol Building in Atlanta. Although not a traditional public forum, the rotunda had historically been open to all sorts of private displays and had become a limited public forum. Id.

112891 F2d 1024, 1029 (2d Cir 1989).

11 The Second Circuit more or less reaffirmed this holding one year later in a decision involving similar facts. Chabad-Lubavitch v City of Burlington, 936 F2d 109 (2d Cir 1991), cert denied, $112 \mathrm{~S} \mathrm{Ct} 3026$ (1992).

While the Americans II display was in a public plaza, the menorah in Kaplan was placed in a public park right in front of city hall; the Kaplan court relied heavily on the proximity to city hall. 891 F2d at 1029-30.

$114891 \mathrm{~F} 2 \mathrm{~d}$ at 1029 .

115 Id at 1030, quoting Widmar, 454 US at 270-71. 
The Kaplan court rejected the menorah display on three grounds. First, the court noted that Burlington had never before granted a permit to a religious group to maintain an unattended display in the park. ${ }^{116}$ Hence, as in Allegheny, one religious group reasonably appeared to have received preferential treatment. Second, the court argued, even if such a forum had been opened to religious symbols, the public forum was "simply a factor to be taken into account in determining whether the context of the display suggests government endorsement."117 Applying the contextual analysis of Allegheny, the court felt that the location of a large and unattended menorah in a public park adjacent to city hall conveyed an unconstitutional message of endorsement that overrode the public forum concerns. ${ }^{118}$ Finally, the Kaplan court relied on a slippery slope argument: "[While] few-if any-of the citizens of Burlington will feel threatened by the unattended, solitary display of a religious symbol of a minority faith," allowing such a symbol would make it "seem permissible to display, standing alone, a symbol of the majority faith."119

The Fourth Circuit, in Smith $v$ County of Albemarle, held that the private display of a nativity scene unaccompanied by any secular symbols on the front lawn of a county office building violated the Establishment Clause. ${ }^{120}$ With reasoning similar to that of Kaplan, the Albemarle court applied Allegheny's contextual arguments and determined that the display conveyed the "unmistakable message . . . of government endorsement of religion . . . ."121 The court also distinguished Widmar by limiting it to its facts: "The associational message [of the particular public forum] is more severe than a simple policy of access to vacant school rooms."122

118 Id at 1029. Other religious groups had received permits to use the park for other events, however, such as rallies and food drives. Id at 1026.

117 Id at 1029.

118 Id at 1029-30.

119 Id. The court also mentioned that allowing a minority religion to set up a display could be perceived as special treatment. Id at 1031. See also Beschle, 57 Brooklyn L Rev at 550 (cited in note 57) (noting that while some of the opponents of the menorah preferred allowing no religious displays in the park, others were "blatantly anti-semitic").

120895 F2d 953, 958 (4th Cir 1990).

121 Id.

${ }^{122}$ Id at 959. 


\section{Applying the Establishment Clause in the Public Forum}

Developing rules of decision for religious display cases requires a court to make at least two legal choices. First, which of the four possible variations of the Court's Establishment Clause jurisprudence should it apply? ${ }^{123}$ Second, should the public forum doctrine act as a bar to the Establishment Clause or should the doctrine merely be one factor to consider under the Establishment Clause analysis?

\section{A. Coercion, Endorsement, or Lemon?}

Justice Scalia has ardently heralded the death of Lemon, and he is not alone. ${ }^{124}$ Nonetheless, both the Lemon test and Justice O'Connor's endorsement test have greater doctrinal support and are theoretically sounder than the coercion tests. Moreover, the issues raised by public religious displays tend not to implicate the more controversial aspects of Lemon and, consequently, tend to obscure any practical differences between the Lemon test and the endorsement test.

Application of a coercion test-especially under Justice Scalia's definition of it in Lee-to public forum analysis would

${ }^{123}$ At present, the endorsement test as derived from Lemon is the law. However, given that in Lee five members of the Court purported to express some kind of coercion test, the possibility of a coercion test's ascendance must be considered. See text accompanying notes 59-70.

${ }^{124}$ See Lee, $112 \mathrm{~S} \mathrm{Ct}$ at 2685 (Scalia dissenting) (noting that "[ $t$ ] strates the irrelevance of Lemon by essentially ignoring it"). Justice Scalia's concurrence in Lamb's Chapel presents the most entertaining description of Lemon to date:

Like some ghoul in a late-night horror movie that repeatedly sits up in its grave and shuffles abroad, after being repeatedly killed and buried, Lemon stalks our Establishment Clause jurisprudence once again, frightening the little children and school attorneys of Center Moriches Union Free School District. . . .

The secret of the Lemon test's survival, I think, is that it is so easy to kill. It is there to scare us (and our audience) when we wish it to do so, but we can command it to return to the tomb at will.

Lamb's Chapel, 113 S Ct at 2149-50 (Scalia concurring).

Other commentators proclaiming Lemon's demise include Note, The Supreme Court-Leading Cases-Establishment of Religion, 106 Harv L Rev 163, 263-64 (1992) (lamenting the demise of the Lemon test after the Court's failure to use it in Lee); Keith A. Fournier, In the Wake of Weisman: The Lemon Test is Still a Lemon, But the PsychoCoercion Test is More Bitter Still, 2 Regent U L Rev 1 (Fall 1992) (arguing that the Court has dropped the Lemon test and adopted a "psycho-coercion test"); Beschle, 57 Brooklyn L Rev at 569-70 (cited in note 57) (comparing the Lemon test to "a family patriarch on his deathbed, spoken of with respect, but not taken all that seriously, while potential heirs jockey for position with an eye toward the inevitable passing"); Sherry, 1992 S Ct Rev at 131 (cited in note 67) ("Despite this lack of an explicit majority, Lee $v$ Weisman clearly signals the death of Lemon and the adoption of a coercion test."). 
probably end most discussion regarding private religious displays. It would be hard to construe a private religious display as actually forcing the public to accept a particular religious belief or face a penalty. This coercion test, however, is not the law and does not make good sense.

First, Lee does not represent the Supreme Court's adoption of a coercion test. In the wake of Lee, Judge Easterbrook has declared the death of Lemon and has employed a coercion test in a case dealing with the Pledge of Allegiance. ${ }^{125}$ No one else has followed this lead; indeed, lower courts have quite consciously continued to apply Lemon, ${ }^{126}$ and the Court once again refused to overturn it in Lamb's Chapel. ${ }^{127}$

Second, even if it qualified as a more popular contender, the coercion test is philosophically flawed. As Justice Souter pointed out in his concurrence in Lee, the Establishment Clause would merge with the Free Exercise Clause if non-establishment stood for nothing more than non-coercion. ${ }^{128}$. Coercion, even in its indirect form, does not capture all that one fears about state-sponsored re-

${ }^{125}$ Sherman $v$ Community Consolidated District 21, 980 F2d 437, 444-45 (7th Cir 1992), cert denied, 113 S Ct 2439 (1993). Judge Easterbrook argues that four Justices in Lee (White, Rehnquist, Scalia, and Thomas) proposed dropping Lemon, one did not rely on it in his concurrence (Souter), and one had proposed dropping it earlier (Kennedy). Id at 445. The argument mischaracterizes Justice Souter's concurrence and ignores Justice Kennedy's distinct refusal to abandon Lemon. See text accompanying notes 58-64.

${ }^{128}$ See, for example, Americans II, 980 F2d at 1543 (noting that "[a]lthough this test has been questioned a number of times, it still appears to govern Establishment Clause cases"); Kreisner $v$ City of San Diego, 1 F3d 775, 780 (9th Cir 1993) (finding no justification to depart from the Lemon test); Berger v Rensselaer Central School Corp., 982 F2d 1160, 1169 (7th Cir 1993) (noting that "Lemon remains the law of the land" in holding that distribution of Gideon Bibles in an elementary school violated the Establishment Clause), cert denied, 113 S Ct 2344 (1993); Jones v Clear Creek Independent School District, 977 F2d 963, 966-68 (5th Cir 1992) (finding that Lemon, a coercion test, and an endorsement test all would permit a student-sponsored benediction at a graduation ceremony), cert denied, $113 \mathrm{~S}$ Ct 2950 (1993); Otway v City of New York, 818 F Supp 659 (S D NY 1993) (questioning the right of participation of a homosexual group in New York's St. Patrick's Day Parade and applying the traditional Lemon test).

${ }_{127} 113 \mathrm{~S} \mathrm{Ct}$ at $2148 \mathrm{n} 7$ ("Lemon, however frightening it may be to some, has not been overruled. This case . . . presents no occasion to do so.").

${ }^{228} 112$ US at 2673. See also Ira Lupu, Reconstructing the Establishment Clause: The Case Against Discretionary Accommodation of Religion, $140 \mathrm{U}$ Pa L Rev 555, 576-80 (1991); Sherry, 1992 S Ct Rev at 134-35 (cited in note 67). 
ligious activity. ${ }^{129}$ It solves the problems and nuances of the Establishment Clause by willing them away. ${ }^{130}$

Lemon, meanwhile, provides at least a useful framework within which to discuss the Establishment Clause, since it takes into account almost any conceivable Establishment Clause violation. Even its critics, most of whom see it as overbroad and insufficiently accommodating to religion, would probably admit this. Additionally, private religious displays do not usually raise the more troubling aspects of Lemon.

Prong one of the Lemon test-whether the state has a secular purpose in its actions-will not be implicated in most cases involving public religious displays. ${ }^{131}$ The Establishment Clause, after all, enjoins government activity; private persons are always free to advocate what they want. ${ }^{132}$ Typically, the government's primary intent with regard to the maintenance of a public forum ${ }^{133}$ is secular: free movement and the free exchange of ideas. Illicit government intent would mean the desire to open a forum specifically to promote religious expression. ${ }^{134}$ There are conceivable, albeit unlikely, situations where the government does precisely that. ${ }^{136}$ From a practical point of view, however, on the rare occasions when such

129 Professor Raz, in a discussion of intolerance and autonomy, makes a related point: If there is a concept of intolerance according to which only coercive interventions are intolerant, then this is not the ordinary notion of intolerance . . . The ideas of toleration and of intolerance identify modes of behavior by their grounds and object. They do not identify them by the means employed. Saying this is not saying that all the manifestations of intolerance are either equally acceptable or equally unacceptable. It is merely to point out that here are concepts that identify actions by their motives and not by the means those motives lead to.

Joseph Raz, The Morality of Freedom 403 (Oxford, 1986).

1so Indirect coercion, as envisaged by Justice Kennedy, runs into an additional problem: the reasonable observer. Because indirect coercion includes an element of perception, it requires the same sort of complex inquiry into whose perception matters that the endorsement test and the effects prong of Lemon contain. As such, indirect coercion would not even be conceptually easier to apply.

131 See, for example, Widmar, 454 US at 271 \& $n 10$ (noting that creating an open forum which does not discriminate on content is a sufficient secular purpose).

132 See Mergens, 496 US at 250, and text accompanying note 98.

133 The maintenance of a forum should be viewed as state action with regard to that forum. See Cass R. Sunstein, Free Speech Now, 59 U Chi L Rev 255, 267-77 (1992).

${ }^{134}$ See Abner S. Greene, The Political Balance of the Religion Clauses, 102 Yale I J $1611,1619-25,1629-30$ (1993) (discussing religious and secular intent with regard to legislative action).

${ }^{135}$ The facts of ACLU $v$ Wilkinson, 895 F2d 1098, 1099-1101 (6th Cir 1990), probably represent such a case. There, the state government constructed a stable with a manger and opened the forum to all who wanted to make use of it. Such an action in and of itself might be said to have no religious effect. However, it is fairly clear that certain religious groups can put a stable to much better use at Christmas time than others can. Hence, one might argue, the government had a religious purpose in creating the forum. 
an intent exists, it would likely manifest itself in the effect of the display. If there is no effect that appears to someone to promote a religion or involve the state in such a promotion, no one will sue or know to sue. Thus, despite the criticism numerous commentators have leveled at Lemon's intent prong, ${ }^{136}$ the question of government intent is largely irrelevant in the realm of private religious displays. And given the difficulty of discovering the "intent" behind a policy in any situation, this may not be such a bad thing. ${ }^{137}$

Prong three of the Lemon test, whether the government risks excessive entanglement in religion by its actions, also would not be implicated in most public forum situations. The Widmar Court, for example, did not consider seriously the entanglement problem, because "the [u]niversity would risk greater 'entanglement' by attempting to enforce its exclusion of 'religious worship' and 'religious speech." "138 A facially neutral policy allowing open access to public fora for all displays avoids the greater problem of having a government try to decide which displays are religious and which are secular. ${ }^{138}$ Hence, the criticism of the uncertainty of the entanglement test is not really relevant. ${ }^{140}$

In essence, then, when we apply the Lemon test in these cases, we need concentrate only on the effects of a display. This basically amounts to applying the endorsement test. The endorsement test did, after all, grow out of the Lemon effects prong, and as Justice Blackmun noted in Allegheny:

${ }^{138}$ See, for example, Edwards v Aguillard, 482 US 578, 636-40 (1987) (Scalia dissenting); Note, "A Picture Held Us Captive": Conceptual Confusion and the Lemon Test, 137 U Pa L Rev 1827, 1830-40 (1989); Mark Tushnet, Reflections on the Role of Purpose in the Jurisprudence of the Religion Clauses, 27 Wm \& Mary L Rev 997, 1002-07 (1986).

${ }^{137}$ The criticism leveled at the intent prong seems correct in many of its ultimate conclusions, but seems to arrive at these conclusions through faulty epistemological arguments. To deny that we can perceive an actual governmental intent does not eliminate the possibility that some actual governmental intent exists. We may never have conclusive proof as to what that purpose is, but it may still exist. This criticism also fails to refute the possibility that our perceptions of government intent may in fact help demonstrate what that intent might be. See generally Immanuel Kant, Critique of Pure Reason (Tuttle, Meiklejohn trans, 1991).

${ }^{138} 454$ US at $272 \mathrm{n} 11$.

139 A policy that prohibited all privately sponsored displays in a public forum would also work. It would, however, require the legislative will to enact such a law.

${ }^{140}$ See David E. Steinberg, Alternatives to Entanglement, $80 \mathrm{Ky} \mathrm{L} \mathrm{J} \mathrm{691,} \mathrm{699-702}$ (1992) (arguing that the political divisiveness prong serves only as "a means of rationalizing a predetermined Establishment Clause conclusion"). The "political divisiveness" element of the entanglement test, whereby state behavior likely to result in religious divisiveness is forbidden, might be said to apply to religious display cases, but this doctrine is neither clear, fully respectable, nor terribly useful. It is best left untouched. 
Whether the key word is "endorsement," "favoritism," or "promotion," the essential principle remains the same. The Establishment Clause, at the very least, prohibits government from appearing to take a position on questions of religious belief or from "making adherence to a religion relevant in any way to a person's standing in the political community."141

Hence, one should use the Lemon test in general, and its endorsement prong in particular, in analyzing cases of private religious displays in public fora. However, making this choice does not end the debate; there is still the question of when endorsement arises.

\section{B. Endorsement and the Reasonable Observer}

An effects test requires consideration of who is affected. While all courts agree that the standard for this test should be the "reasonable observer," they disagree over who this observer is. Indeed, this is the central dispute in the lower courts.

Some courts desire a very stringent definition of the reasonable observer. Americans II and Kreisner, drawing on Justice O'Connor's language in Lynch and Allegheny, emphasize that the reasonable observer knows the history and most of the relevant facts behind the display. ${ }^{142}$ The Americans II court would restrict the reasonable observer to the level of a well-informed individual who knew what was going on in the city, read the papers, and understood any disputes. ${ }^{143}$

Kaplan and Albemarle would expand the reasonable observer to any person who might have been viewing the display and might have reasonably perceived government sponsorship of a religious message. ${ }^{144}$ They place greater emphasis on the possibility of individual harm and deny that the reasonable observer knows all the intricacies of a display and its history. This wider interpretation implicitly includes the perspective of what Professor Tribe has called the "reasonable non-adherent."145 The reasonable non-adherent is not "hypersensitive," but may be, because of her position

141492 US at 593-94, quoting Lynch, 465 US at 687.

142 Americans II, $980 \mathrm{~F} 2 \mathrm{~d}$ at $1544-45$ ("Justice O'Connor . . . has emphasized that, when adopting the perspective of the reasonable observer, courts must consider all of the facts presented in each case."); Kreisner v City of San Diego, 1 F3d 775, 784 (9th Cir 1993). While Justice O'Connor's views are persuasive, it is Justice Blackmun who actually wrote the endorsement test into a majority opinion.

${ }^{143} 980 \mathrm{~F} 2 \mathrm{~d}$ at 1544.

14 See Kaplan, 891 F2d at 1030; Albemarle, 895 F2d at 957-58. 1988).

14 Laurence Tribe, American Constitutional Law $\S$ 14-15 at 1293 (Foundation, 2d ed 
as an outsider, offended by actions that "may seem so natural and proper to adherents as to blur into the background noise of society." 146

The wider interpretation of the reasonable observer better reflects the core constitutional value of the Establishment Clause-tolerance of religious diversity. This interpretation admittedly protects Establishment Clause interests at some cost to free exercise. Nonetheless, this concern is outweighed by three others. First, private religious expression continues to be protected in private areas, and the Establishment Clause does not reach those areas. ${ }^{147}$ Second, the narrow interpretation makes the reasonable observer a member of the majority religion, ${ }^{148}$ ignoring the fact that the Establishment Clause ostensibly protects minority injury. Finally, the narrow interpretation, with its presumption that a viewer is well-informed as to a display's history, falsely assumes that if most people know something, then those few that do not are not hurt by that lack of knowledge. ${ }^{149}$

Judge Easterbrook has criticized the use of a "reasonable observer" test on the grounds that it creates the "obtuse observer" problem. According to Judge Easterbrook, allowing a wide interpretation of the reasonable observer gives prospective observers a heckler's veto over religious speech. Why, he asks, should a cranky person who reads governmental endorsement into some other person's free exercise of religious expression be allowed to silence that person? ${ }^{150}$

The answer lies in the Establishment Clause. We consider avoiding the appearance of government endorsement of religion important enough that we curb some forms of expression. ${ }^{151}$ Moreover, the reasonable observer standard merely represents an at-

146 Id.

147 It is interesting to note that all problems might be solved if people merely practiced their religions on private property. In the December 11, 1992 episode of the CBS television series Picket Fences, a dispute erupted in a small town when one Jew sought to enjoin the annual Christmas display and pageant at the public school. After much debate, including a court scene in which litigants discussed the "two-plastic reindeer rule" and other features of Establishment Clause jurisprudence, everything was solved by moving the celebration to the local Roman Catholic church. If only life could imitate art.

148 This is akin to applying the "reasonable man" standard to reasonable women.

149 Note also that those least informed about a display are likely those who do not subscribe to the display's religious message.

${ }_{150}$ See Doe v Small, 964 F2d 611, 630 (7th Cir 1992) (Easterbrook concurring). But see Tribe, American Constitutional Law §§ 14-15 at 1293.

${ }^{251}$ See Kathleen M. Sullivan, Religion and Liberal Democracy, 59 U Chi L Rev 195, 206 (1992) ("This disability is unique to the Religion Clauses. No other topic besides religion is off limits to government in the course of its own activities, as opposed to its regula- 
tempt (made often enough in other areas of the law and in ethical reasoning) to analyze objectively the effect on the "average" person of viewing a religious display in a public forum.

The argument that an obtuse observer who spends his time looking for an endorsement of religion will possess a "heckler's veto" over private religious displays holds little weight. True, those who sue to enjoin such displays are typically those adversely affected by them. But a religious display is unconstitutional if it encourages those who support the display's message to believe that the state endorses them. Indeed, that possible sentiment is probably more dangerous, since it encourages a false belief in a non-existent consensus, allowing the majority to marginalize all other religious views. The Establishment Clause exists, at least in part, to protect minority religious views from being overwhelmed. Only a wider conception of the reasonable observer adequately protects that interest.

In fact, the heckler's veto argument can also work the other way. Religious symbols are usually best, if not solely, understood by that religion's adherents. The display of such a symbol acts as a perceived wink of approval from the government. At times, it may well take an obtuse observer to ferret out an unconstitutional display.

\section{Incorporating the Public Forum Doctrine}

As Widmar and Mergens indicate, one cannot and should not discriminate against religious expression or speech out of fear of religious zealots. This is especially true in the public forum. ${ }^{162}$ So long as the government has a facially neutral policy of allowing groups to participate in an open forum, the forum must be open to religious speech.

Yet all arguments that persons are entitled to free speech and free expression in the public forum must respect the restraints of the Establishment Clause. Otherwise, as Judge Feinberg noted, we reduce the Establishment Clause to a nullity. ${ }^{163}$ The state may not restrain free speech arbitrarily, but it must impose restraints

tion or imposition of conditions on private activities. There is no political establishment clause.").

${ }^{162}$ See Laycock, $81 \mathrm{Nw}$ U L Rev at 9 (cited in note 88) (noting with regard to the Equal Access Act that most persons opposed to permitting religious speech in the public forum "would not take this position with respect to speech on any other subject. But with respect to religious speech, they have been led into error by their fear of establishment.").

${ }^{283}$ Kaplan, 891 F2d at 1029. 
where the speech is both religious and seems to represent the views of the government. Were courts to evaluate open forum policies in a vacuum, such policies would almost always be held constitutional. However, while it is important to consider the government policy that allows an open forum to exist, the inquiry cannot stop there. ${ }^{154}$ Religious display cases unfold in fact-specific scenarios, each of which must be evaluated on its own merits. ${ }^{155}$ The state action involved in these cases concerns the regulation or creation of the public forum, and the Establishment Clause analysis must consider to what extent the state is actually or apparently enmeshed in a particular private display, even if the state has taken no special action vis-à-vis that display.

Finally, the Seventh Circuit's argument in Doe v Small, that Widmar's decision concerning a limited public forum compels the same conclusions for regular public fora, is flawed. ${ }^{156}$ In a limited public forum, the public's access is generally restricted, and most outsiders will not be exposed to the situation. Under the facts of Widmar and Mergens, only the students at a school would be affected, and they would understand that the school was not supporting particular student groups. Students are younger, more immature, and more impressionable than adults, but they also understand the mechanics of school policies and politics and are forced to deal with them on a daily basis. The reasonable observers (the students) affected by a high school's open-club policy are very familiar with how that policy works.

In contrast, no such assumptions can be made about the reasonable observer of a religious display in a public forum. He or she will probably know far less about the mechanics of how the display got there than a student would know about the origins of a club. When a group of students meets behind closed doors to pray or talk about God, other students are little affected, if at all. But when a person places a religious display in a public forum, religious beliefs are necessarily put on display for the world to see.

Consequently, it seems patently absurd not to apply Allegheny and its line of Establishment Clause jurisprudence when dealing with private religious displays in the public forum. The

${ }^{154}$ But see Kreisner $v$ City of San Diego, 788 F Supp 445, 450 (S D Cal 1991) (going no further than inquiring whether the government's open forum policy violated the Establishment Clause and finding that it did not), aff'd, 1 F3d 775 (9th Cir 1993).

${ }^{155}$ See Lee, $112 \mathrm{~S}$ Ct at 2661 ("Our Establishment Clause jurisprudence remains a delicate and fact-sensitive one....").

${ }^{186}$ See Doe, 964 F2d 611, discussed in note 111. 
urge to cut the Gordian knot of Establishment Clause jurisprudence by employing a coercion test or by denying the relevance of the Establishment Clause to private religious displays in the public forum must be avoided. But having decided to apply the Lemon test (or its elaboration in the endorsement test) to these displays, the issue then becomes exactly how one does this.

\section{A Modest Proposal and its Application}

Considering the cases discussed in Section II, it becomes clear that a religious display in a public forum will pass constitutional muster if it satisfies one of two conditions. If the display has been secularized to the point that its message is not "religious," the Establishment Clause cannot bar the display. Alternatively, if there is no doubt to observers that a display is private and conveys no message of government endorsement, then the display also satisfies the Establishment Clause. The two inquiries are related and at times require similar analyses, but they are distinct.

This Section argues that courts should ordinarily presume that a display is religious and focus instead on discerning whether the display appears to be government-sponsored in assessing possible constitutional violations. This proposal stems from the observation that while courts usually falter in distinguishing the religious from the secular, they often have more success in separating the private from the public.

A. What Makes a Display's Effect Secular; What Makes it Religious

The most puzzling and difficult part of the Supreme Court's analysis is determining when a display has a "secular" effect and when it has a "religious" one. As Professor Tushnet has written, this difficulty arises because of the unique nature of religion: "[T] $T$ he jurisprudence of the religion clauses is a mess not because we do not understand the Constitution, but because we do not understand religion." ${ }^{157}$ Religious symbolism lends itself to very individual and private understandings that are not easily accessible to

${ }^{167}$ Tushnet, $27 \mathrm{Wm} \&$ Mary L Rev at 1008-09 (cited in note 136). 
others. ${ }^{108}$. Accordingly, courts should avoid this particular inquiry when possible and instead presume a display is religious. ${ }^{168}$

The Court attempted to distinguish the secular from the religious in Lynch and Allegheny, and the decisions do reveal a tenuous continuum along these lines. Lynch, on the one hand, provides the baseline for acceptable religious displays. A religious symbol (a crèche) overwhelmed by secular trappings (wishing wells, candy canes, reindeer, etc.) constitutes a secular display. ${ }^{160}$ Allegheny, on the other hand, indicates that the government may not sponsor a lone religious symbol (in that case, $a$ crèche) in a public forum. ${ }^{161}$ Everything in between remains open to debate.

Thus, the Court has apparently endorsed, as many lower courts have apparently embraced, what is known as the "St. Nicholas too" test, whereby a clearly religious (and unconstitutional) display can be transformed into a semi-secular (and constitutional) one when surrounded by more harmless and universal symbols. ${ }^{162}$ While a crèche alone sends a purely religious message, a crèche coupled with commercial symbols of the Christmas season does not.

There are two critiques of this inquiry into the religious message of a display. The first is less ambitious and easily addressed; the second both broader and more damaging.

The first critique asks whether the Establishment Clause applies only to Christianity; even if we have to ask what is secular and what is religious in its context, can we not at least limit the inquiry to Christian endorsements? After all, for example, Jews represent less than three percent of the American population. Thus, except in those few municipalities in which Jews constitute a substantial minority, it is unlikely that a "reasonable observer" would think that the state was advocating Judaism by allowing private citizens to erect a menorah in front of city hall. As Judge Boggs noted in Americans II, "[s] urely the court is not ... argu[ing] that the average Grand Rapids citizen (or any informed

${ }^{158}$ See William James, The Varieties of Religious Experience 39 (Harvard, 1985) ("[D]o what we will with our defining [the nature of religious experience], the truth must at last be confronted that we are dealing with a field of experience where there is not a single conception that can be sharply drawn.").

${ }^{159}$ Of course, this argument assumes that the display reasonably appears to be religious. I am not proposing that a court accept a plaintiff's allegations as true without question.

${ }^{180} 465$ US at $671,685$.

${ }^{181} 492$ US at 598-602.

${ }^{162}$ The origins of this test are discussed in note 52. 
observer) believes that the city, intentionally or unintentionally, is endorsing the Lubavitcher sect of Orthodox Judaism by allowing the Chabad House display."163 The same analysis would apply to other minority religions as well; the state usually only appears to endorse a religion when it advocates a conceivably majoritarian position. ${ }^{164}$

This first critique faces substantial problems. First, if Jews, Muslims, Buddhists, and other religious minorities were allowed free reign to set up their symbols in public, it might pose an equal protection/access problem. Mergens already disposed of this problem by invalidating prima facie religious/non-religious distinctions for private actors in the public forum, at least in the context of the Equal Access Act. Moreover, although the government might not appear to be endorsing Judaism as against all other religions when it allows Hassidim to erect a menorah, it could appear to other Jews that the state endorsed the Hassidim over other branches of Judaism. ${ }^{165}$ Additionally, courts would have to consider which Christian sects form the majority. Such distinctions would unnecessarily entangle government in religious questions. ${ }^{168}$

The second critique goes far deeper than the first and attacks the very notion of using contextual arguments to determine how religious a display is. As critics have often noted, religious contextualism is counter-intuitive and borders on the absurd. ${ }^{167}$ First, it leads to more grandiose displays: you cannot display a crèche, but you can display a crèche and a Christmas tree. Ironically, more becomes better, or at least safer. Second, groups seeking to pass on a banc).

${ }^{163}$ Americans $I, 1992$ US App Lexis $7513,{ }^{*} 61$, rev'd, 980 F2d 1538 (6th Cir 1992) (en

164 One could defend the practice of advancing minority religions along the same lines as one defends affirmative action programs. After all, affirmative action effectively discriminates against the majority in an effort to rectify past or present biases. The problem, of course, is that no such policy is really needed in the realm of religion, nor would it make sense. See also ACLU v City of Birmingham, 791 F2d 1561, 1566 (6th Cir 1986) ("Since the majority does not need its protections, the Bill of Rights was adopted for the benefit and protection of minorities. From the beginning, Christians have constituted a majority in America and non-Christians are acutely aware of this fact."); United States $v$ Carolene Products, 304 US 144, 152 n 4 (1938).

${ }^{165}$ See Ran-Dav's County Kosher, Inc. $v$ New Jersey, 129 NJ 141, 162-65, 608 A2d 1353, 1363-65 (1992), cert denied, 113 S Ct 1366 (1993) (holding that New Jersey's establishment of a commission to determine whether products met standards of Orthodox Jewish kosher law constituted an unconstitutional entanglement of government and religion leading to a preference of one kind of Judaism over another).

${ }^{168} \mathrm{It}$ is because of this sort of situation that the endorsement and coercion tests cannot and in the end do not completely abandon the Lemon framework.

${ }^{167}$ See text accompanying note 52 . 
religious message are encouraged to cloak it in quasi-secular trappings. The message to the "reasonable observer" on seeing such displays may be that the holiday season you see around you depends on a particular religious belief and you better not forget why it is that people go around wishing one another peace on earth and good will towards men. Thus, far from making the message "secular," such extensive displays may foster a belief that a particular religion lurks behind everything. ${ }^{168}$ Third, such displays offend by sugar-coating a poisoned pill. To use the Christmas example, early missionaries incorporated the "non-religious" aspects of Christmas (decorated trees, mistletoe, gift-exchanging, etc.) to convert pagans and make the religion more palatable to non-believers. Finally, it is offensive to religion to assert that a religious symbol loses its power merely because it is surrounded by other symbols. ${ }^{169} \mathrm{~A}$ crèche remains a holy symbol to Christians no matter how many reindeer encircle it.

Unfortunately, the Court has adopted this reasoning, most lower courts have followed suit, and much case law exists that tries to distinguish the secular from the religious. For the reasons listed above, most of these inquiries have proven wholly unsatisfying. However, because of the nature of religion, this is to be expected. Consequently, courts should avoid this inquiry when possible and assume when in doubt that a display is religious. Instead, they should focus on whether a display is or can be perceived as government-sponsored.

\section{B. What Can and Cannot be Perceived as Government Speech}

Whereas contextual arguments are of dubious value in separating the religious from the nonreligious, they prove helpful in separating the public from the private. This is because a public/ private distinction depends more on objective physical perception and less on personal symbolic understanding. The public/private distinction can therefore benefit greatly from a refined contextual argument. This can best be achieved by creating the rebuttable presumption that all displays in the public forum are government-

${ }^{168}$ After all, St. Nicholas was a saint.

${ }^{169}$ See Phillip Kurland, The Religion Clauses and the Burger Court, 34 Cath U L Rev 1, 13-14 (1984); see also Eric Zorn, Good to be a holy day or a holiday?, Chicago Tribune, $\S 2$ at 1 (Apr 8, 1993) (noting that Illinois would have to defend its Good Friday holiday against constitutional attack with arguments that "inevitably cheapen and disrespect the holiday. It all makes you wish that Casimir Pulaski had been born around Easter."). 
sponsored and by liberally allowing disclaimers to rebut this presumption.

1. Presuming all displays in public fora are governmentsponsored.

All analyses of religious displays in public fora should begin with the presumption that the displays are supported by the government and allow various factors to rebut or reinforce this presumption. ${ }^{170}$ As noted earlier, once religious speech is reasonably perceived as government speech, it becomes invalid. ${ }^{171}$ But if one can eliminate this perception, no Establishment Clause problems remain.

The presumption is irrebuttable in a number of situations. First, when the government permits a religious display in a closed forum, the fact that other groups ordinarily cannot use the area necessarily indicates preferred treatment and therefore government endorsement. ${ }^{172}$ Second, where a forum is not "robust" and tends to be used by only one group, the presumption is not rebuttable. ${ }^{173}$ Finally, if a display is permanent and other groups cannot use the same land or space, there arises an equal access problem akin to that of permitting a display in a closed public forum. In such cases, one cannot refute the perception of government support.

By the same token, the fact that the government issues permits or provides nominal assistance in maintaining the display is normally irrelevant. So long as such assistance is minimal-only

170 This presumption is analogous to that in property law which assumes that any structure on or imbedded in the land belongs to the owner of the land. See, for example, Chance $v$ Certain Artifacts Found and Salvaged from THE NASHVILLE, 606 F Supp 801, 806 (S D Ga 1984), aff'd, 775 F2d 302 (11th Cir 1985); Klein v Unidentified, Wrecked and Abandoned Sailing Vessel, 568 F Supp 1562, 1566 (S D Fla 1983), aff'd, 758 F2d 1511 (11th Cir 1985); Bishop v Ellsworth, 91 Ill App 2d 386, 391, 234 NE2d 49, $51-52$ (1968).

171 Note that one cannot limit the inquiry to situations where the government is the primary speaker. If there is any taint of endorsement exceeding a bare and incidental minimum, such effect should trigger the Establishment Clause. The government looming behind a private religious display as a silent partner violates the Establishment Clause just as much as when the government is the primary speaker. Compare Judge Kennedy's concurring opinion in the vacated Americans I panel decision, which would have held that if the speech appears to the reasonable observer to be primarily that of the government, then "the resulting speech is easily characterized as an impermissible endorsement." Americans I, 1992 US App LEXIS 7513 at *45-46 (Kennedy concurring).

172 See, for example, Allegheny, 492 US at $600 \mathrm{n} 50$.

173 Mergens, 496 US at 268 (Marshall concurring) (arguing that "the absence of a truly robust forum that includes the participation of more than one advocacy-oriented group" tends to vitiate the essence of the public forum). 
that required to ensure the safety and physical appearance of the site-and is offered to all similar displays, it has no effect on the analysis. ${ }^{174}$

The presumption of government sponsorship avoids many of the problems of determining who is the reasonable observer, as, for example, with regard to government ownership. ${ }^{175}$ Admittedly, the presumption suggested by this Comment gets around the question by answering it in favor of a wider definition of the reasonable observer, one more apt to perceive a government endorsement of religion. Yet this presumption is easily overcome by a forceful and visible disclaimer. In effect, the presumption occupies a middle ground between elevating the Establishment Clause over the Free Speech and Free Exercise Clauses and denying the Establishment Clause's relevance to a debate over private expression.

There are two major potential difficulties with the presumption. First, one might contend, it is insufficiently accommodating to religion. After all, "[r]eligionists no less than members of any other group enjoy the full measure of protection afforded speech, association, and political activity generally."176

One cannot justify inhibiting religious expression on the ground that it may offend some members of society, any more than flag burning could be so justified. ${ }^{177}$ But the concerns of the Establishment Clause in preventing government endorsement of religion allow restrictions here. Moreover, as argued below, a liberal allowance of disclaimers should effectively counterbalance this concern.

Second, one might argue that the presumption fails to take into account the different influences surrounding different sorts of public fora. Taking their cue from Allegheny, courts have repeat-

174 Further assistance, such as issuing proclamations announcing the display or paying for the display's storage, probably do change the situation. See Doe, 964 F2d at 621-22 (suggesting that the city could comply with the Establishment Clause by rescinding its proclamation on behalf of religious paintings, allowing other groups to use the foundations built for the paintings, or posting a larger sign disclaiming ownership). See also Allegheny, 492 US at $600 \mathrm{n} 50$.

${ }^{175}$ See, for example, Justice Brennan's critique of Justice Blackmun's use of the reasonable observer in Allegheny, 492 US at 642-43 (Brennan concurring in part and dissenting in part) ("I shudder to think that the only 'reasonable observer' is one who shares the particular views on perspective, spacing, and accent expressed in Justice Blackmun's opinion, thus making analysis under the Establishment Clause look more like an exam in Art 101 than an inquiry into constitutional law.").

${ }^{176}$ Americans I, 1992 US App LEXIS 7513 at *55 (Boggs dissenting), quoting McDaniel $v$ Paty, 435 US 618, 641 (1978) (Brennan concurring).

${ }_{177}$ See id at *56. See also Texas v Johnson, 491 US 397, 414 (1989) ("[A] bedrock principle underlying the First Amendment [ ] is that the government may not prohibit the expression of an idea simply because society finds the idea itself offensive or disagreeable."). 
edly stated that religious displays appear more invidious when surrounded by the trappings of government; a crèche in front of city hall appears more coercive than one sitting in the middle of a lonely park on the outskirts of town. ${ }^{178}$

While this may be true, it ignores the fact that any religious display that might appear to belong to the government creates an impression of government endorsement of religion. Simply because an endorsement is "clearer" in one context than in another does not mean that both contexts do not suggest government endorsement. Indeed, a display far from the center of government might be an even more potent endorsement, since it implies that such endorsements are widespread and reach everyone; the cranky dissenter cannot even feel safe in his own neighborhood.

\section{What can rebut the presumption?}

Metaphorically, one might conceive of the Establishment Clause as a lightning bolt ready to strike any apparently government-sponsored display. Therefore, anything near the display indicating private ownership can act as a lightning rod and divert that presumption of ownership.

a) Disclaimers of ownership and endorsement. Disclaimers solve most problems raised by Establishment Clause analysis in the public forum. This does not mean that disclaimers will always suffice, but in most situations they should be adequate. ${ }^{179}$ Signs merely declaring sponsorship are not disclaimers. A sign reading "This Menorah Sponsored by Chabad-Lubavitch" or "This Display Donated by the Holy Name Society" merely show private involvement in the display. A disclaimer must indicate in no uncertain language that the government has nothing whatsoever to do with the display and that government permission to erect the display in no way connotes its endorsement of the display's message.

17 In Doe, for example, the court took notice of the fact that the display it upheld was in a park "far removed from the seat of government." 964 F2d at 619. Compare Kaplan, 891 F2d at 1028 (holding unconstitutional a menorah display located "right in front of City Hall-the very phrase 'is commonly used as a metaphor for government' "), quoting American Jewish Congress $v$ Chicago, 827 F2d 120, 128 (7th Cir 1987).

179 The use of disclaimers is by no means an original idea. See, for example, Doe, 964 F2d at 621; Kaplan, 891 F2d at 1033 (Meskill dissenting). No court, however, has really adequately articulated the proper requirements for disclaimers. 
Otherwise, one could reasonably think that both the private party and the government sponsored the display. ${ }^{180}$

A disclaimer's adequacy should be measured by its visibility to the average person viewing the religious display. ${ }^{181}$ While this standard should be more demanding than that advocated by the Americans $I I$ court, ${ }^{182}$ this does not necessarily imply that huge neon signs must accompany every crèche. As a general rule, it would make sense to require a disclaimer with lettering as large as any other lettering on the display. In the absence of such lettering, a reasonably visible sign should attend the display. ${ }^{183}$

In some cases, however, a very large disclaimer might be necessary. For example, if the display is meant to be viewed from the air or by a passing car, then someone flying in a plane or driving by must be able to see the disclaimer. Alternatively, if a menorah is placed on the top of a tall public building, its disclaimer must be visible to all those who would see the display from the ground. Admittedly, this rule effectively requires huge and perhaps unwieldy disclaimers for these types of displays; in these few instances, ${ }^{184}$ the domineering nature of such displays mandates equally effective disclaimers (or simply scaling back the display).

Disclaimers also solve the problems of context created by the essential nature of symbols. Symbols have different effects on different people at different times, and it becomes impossible to determine how one should reasonably interpret them. A swastika can serve both as a reminder of Nazi tyranny and as a symbol of Buddhism. Indeed, finding a consensus on who knows or feels what

180 See Allegheny, 492 US at 600-01 ("[T] sense of promoting someone else's message."). The Kaplan court may also have perceived this distinction when it relied on Allegheny in denying effect to a disclaimer. Kaplan, 891 F2d at 1029 \& n 5. In all likelihood, however, the Kaplan dissent was correct in noticing that the majority failed to distinguish between a disclaimer's ability to diminish a display's religious effect and a disclaimer's ability to demonstrate lack of government involvement. Id at 1033-34 (Meskill dissenting).

${ }^{181}$ This should be limited to reasonably foreseeable viewers. An exception, for example, might be an American equivalent of the "cross" on the television tower at Berlin's Alexanderplatz. Because of an unexpected reflective pattern, the globe-shaped structure at the top of the tower always appears to have a cross on it. The East German government, which had the structure built, obviously never intended the cross to appear there, and it certainly was not a foreseeable consequence.

${ }^{182}$ See 980 F2d at 1540 (accepting two illuminated signs measuring 2 feet by 3 feet, next to a 20 -foot high menorah).

${ }^{183}$ The phrase "reasonably visible" admittedly lacks the clarity of a bright-line rule and has the potential to create conflicts. Nonetheless, where parties cannot agree whether the letters should be one or two inches high, a court can probably settle the issue quickly.

184 One would not expect to encounter many such displays anyway. 
about a particular religious symbol, especially in heterogenous modern America, is nearly impossible. An unambiguous declaration on a prominently posted sign stating that the government does not own or endorse the display would avoid the tricky problems such symbolism raises.

Critics have lodged two divergent complaints against disclaimers. On the one hand, those who wish to ban religious displays from the public forum sometimes argue that permitting religious speech in a public forum "in and of itself" confers an "imprimatur of state approval on religious sects and practices."185 Hence, disclaimers would be meaningless. This argument has some merit, but it goes too far. ${ }^{186}$ Indeed, in some situations, such as the closed public forum, no disclaimer could ever suffice. ${ }^{187}$ Yet a clear and honest disclaimer should be enough, most of the time, to show that the government is not involved and thus is enough to avoid violating the Establishment Clause.

Additionally, a disclaimer will serve its purpose even if a private person erected a display on public ground with the intent of creating an "aura" of public support for the display ${ }^{188}$ _ by nullifying the effect of such intent. Even if someone hoped to use a public forum to display a religious item in order to suggest that the weight of the state is behind her position, a prominent disclaimer would prevent this result.

On the other hand, some might argue that the requirement of a large disclaimer is excessive and mars the view of the display. While this complaint has some validity, it is sacrificed for the sake of a clearer rule. The disclaimer requirement is obtrusive, but it is minimally so. Moreover, if a party feels that a disclaimer ruins the beauty of a display, she can find private ground on which to display it.

185 Chabad-Lubavitch of Georgia v Harris, 752 F Supp 1063, 1067 (N D Ga 1990), quoting Kaplan, 891 F2d at 1033 (Meskill dissenting). Like the Harris court and the Kaplan dissent, most courts have rejected this notion. See ACLU $v$ Wilkinson, 895 F2d 1098, 110306 (6th Cir 1990); McCreary v Stone, 739 F2d 716, 726-27 (2d Cir 1984), aff'd as Scarsdale $v$ McCreary, 471 US 83 (1985).

${ }^{186}$ See, for example, Sheldon Nahmod, The Public Square and the Jew as Religious Other, 44 Hastings L J 865 (1993) (arguing for banning religion from the "public square").

${ }^{187}$ See, for example, Allegheny, 492 US at 600-01 (holding that where a religious display sat in a closed public forum, no disclaimer could dispel the message of government endorsement of religion).

${ }^{188}$ See Burelle $v$ City of Nashua, 599 F Supp 792, 795 (D NM 1984) (noting that a display of a crèche on public property received support precisely because of the impression conveyed of governmental approval). 
b) Other methods. Disclaimers, while the most obvious and consistent method of ensuring the perception of private ownership, are not the only means available of rebutting the presumption of government ownership. Several courts, for example, have ruled that so long as persons are tending to the display, the government is not deemed to be a sponsor of the display. ${ }^{180}$ The individual, in essence, acts as a human lightning rod, and individuals are presumed to be acting on their own and not on behalf of the government. ${ }^{190}$

Finally, it should be noted that all of these attempts at disclaiming ownership are irrelevant if the government is in fact sponsoring or endorsing the display. ${ }^{191}$ The phenomenological analysis cannot be used to dispel actual endorsement of the display.

\section{The problem of history.}

The proposed solution leaves unaddressed one last problem: how one should view "historical" arguments for maintaining religious displays in public fora? What should happen when a private group has sponsored a nativity scene in a public park for 100 years? On the one hand, as Justice Kennedy might argue, the display has become part of an acknowledged civic tradition and is not purely religious. On the other hand, the display might be all the more overbearing because of this long tradition. To take an extreme analogy, the fact that schools had been "separate but equal" for a long time by 1954 did not mandate the continued acceptance of that "tradition." "192

The endorsement test does take history into account, but with less reverence than the coercion tests. In the endorsement test world, a religious message repeated over time (for example, "In God We Trust" on the back of coins) does lose any semblance of government endorsement of religion. ${ }^{193}$ Similarly, an historical tradition of one group's or individual's sponsorship of a display might be so pervasive that this tradition in and of itself rebuts government sponsorship. So long as there is no accompanying tradition of

${ }^{189}$ See Kaplan, 891 F2d at 1030; Allegheny, 492 US at 599.

190 Of course, if the individual is clothed in governmental authority as she tends to the display, this presumption is reversed.

${ }^{102}$ See, for example, Libin v Town of Greenwich, 625 F Supp 393, 396 n 1 (state actor erected cross in an arguably limited public forum).

${ }_{102}$ See Tribe, American Constitutional Law \$\$ 14-15 at 1291 (cited in note 145).

${ }^{303}$ But see Harris v City of Zion, 927 F2d 1401, 1413-15 (7th Cir 1991), cert denied by City of Rolling Meadows $v$ Kuhn, 112 S Ct 3054 (1992) (holding unconstitutional a city seal containing a Latin cross). 
government involvement with the display, this should suffice. ${ }^{194}$ Other claims to tradition, however, are more suspect.

\section{CONCLUSION}

Using a presumption of government sponsorship of religious displays in the public forum, with an allowance to rebut the presumption through appropriate disclaimers, will solve the problems associated with such displays. This Comment has assumed that a clearer rule than the one proposed is neither wise nor politically acceptable. At first glance, banning every religious display from the public forum may not seem all that horrible. After all, no one is prohibited from practicing his own religion on private grounds, and we would thereby wholly avoid the risk of apparent government endorsement of religion. But such a suggestion would be practically unworkable in this very religious nation, while the Free Exercise and Free Speech Clauses would seem to require permitting religious expression to have some voice in the public forum. At the same time, giving religious displays a free run of the public forum would be politically unacceptable as well. It would also tend to eviscerate the Establishment Clause. Allowing the displays while requiring real and effective disclaimers strikes a balance between these competing concerns. And with this balance, perhaps the City of Burlington can begin to spend its resources on something more useful than attorneys' fees.

194 This form of the historical argument as proposed in Marsh, in Lynch, by Justice Kennedy in his dissent in Allegheny, and by Justice Scalia in his dissent in Lee seems perfectly reasonable and uncontroversial. The argument that the same applies to the content of the display is not.

Note that to the extent that the Lemon test and the endorsement test might produce different results, it would be on historical issues. Lemon gives no quarter to such arguments. See Marsh, 463 US at 796-801 (Brennan dissenting). See also note 20, discussing Marsh. And while applying Lemon here would demonstrate greater intellectual consistency, Marsh and other cases have probably ruled out that possibility. 
